\title{
ANALISIS IMPLEMENTASI PROGRAM PENDIDIKAN GRATIS DI MADRASAH IBTIDAIYAH DARUL IBAD AJUNG JEMBER
}

\author{
IDA MUSTIKAWATI* \\ MIFTAHUL JANNAH \\ Program Studi Ilmu Administrasi Negara \\ Sekolah Tinggi Ilmu Administrasi Pembangunan Jember \\ *Email: ida_mustikawati@stiapembangunanjember.ac.id
}

\begin{abstract}
ABSTRAK
Penelitian ini bertujuan untuk mendeskripsikan implementasi pendidikan gratis. Penelitian ini menggunakan penelitian kualitatif, dengan studi kasus. Teknik pengumpulan data dilakukan dengan observasi, wawancara, dokumentasi.. Analisis data dilakukan secara kualitatif.

Hasil penelitian ini menunjukkan bahwa pendidikan gratis di MI Darul Ibad sesuai dengan Peraturan Bupati Jember Nomor 65 Tahun 2016 tentang Pedoman Penyelenggaraan Pendidikan Gratis di Kabupaten Jember telah terlaksana dengan baik. Hal ini terbukti dengan pemenuhan yang menjadi indikator kebijakan pendidikan gratis terdiri dari Ukuran dan Tujuan Kebijakan, Sumber-sumber kebijakan, Komunikasi antar Organisasi dan Kegiatan-Kegiatan Pelaksanaan, Karakteristik Badan-Badan Pelaksana, Kondisi-kondisi Ekonomi, Sosial, dan Politik. Kecenderungan Pelaksana (Implementator).

Meskipun demikian masih ditemui dua indikator Kebijakan pendidikan gratis belum terimplementasi dengan baik, yaitu: (1) penyaluran dana tidak dilakukan sesuai dengan petunjuk teknis PPG dan mengalami keterlambatan pencairan dana; dan (2) kurangnya pemahaman masyarakat atau orang tua yang banyak beranggapan bahwa dana pendidikan gratis seluruhnya di tanggung pemerintah.
\end{abstract}

Kata Kunci: Implementasi, Program Pendidikan Gratis 


\section{PENDAHULUAN}

Di Indonesia semua penduduk wajib mengikuti program wajib belajar pendidikan dasar selama sembilan tahun, enam tahun di Sekolah Dasar/Madrasah Ibtidaiyah dan tiga tahun di Sekolah Menengah Pertama/Madrasah Tsanawiyah. Undang-Undang Nomor 20 Tahun 2003 tentang Sistem Pendidikan Nasional Pasal 34 ayat 3 menyebutkan bahwa wajib belajar merupakan tanggung jawab negara yang diselenggarakan oleh lembaga pendidikan Pemerintah, Pemerintah Daerah, dan masyarakat. Konsekuensi dari amanat undangundang tersebut adalah Pemerintah dan Pemerintah Daerah wajib memberikan layanan pendidikan bagi seluruh peserta didik pada tingkat pendidikan dasar dan pendidikan Menengah serta satuan pendidikan lain yang sederajat. Untuk memberikan layanan pendidikan bagi seluruh peserta didik pada tingkat pendidikan dasar dan menengah, Kabupaten Jember akan berupaya meringankan beban masyarakat terhadap pembiayaan pendidikan dalam rangka rintisan program Wajib
Belajar 12 Tahun yang terjangkau dan bermutu berperan dalam percepatan capaian Standar pelayanan minimal (SPM) dan capaian Standar Nasional Pendidikan (SNP) Kabupaten Jember Tahun 2017.

Salah satu program unggulan pemerintah Kabupaten Jember dalam bidang pendidikan adalah Pendidikan Gratis. Pendidikan Gratis adalah suatu kebijakan yang telah ditetapkan oleh Pemerintah Kabupaten Jember agar permasalahan biaya sekolah dapat teratasi, Hal ini dilakukan karena masyarakat menganggap terlalu besar biaya untuk menyekolahkan anaknya. Pendidikan Gratis adalah bantuan dana pendidikan dan salah satu program unggulan Pemerintah Daerah Kabupaten Jember. Program pendidikan gratis adalah salah satu layanan (service).

Bupati Jember menegaskan konsep pendidikan gratis dalam rancangan daerah Rencana Pembangunan Jangka Menengah Daerah ～(RPJMD) 2016-2021. Program Pendidikan gratis 
berdasarkan Peraturan Pemerintah Nomor 66 tahun 2010 tentang perubahan atas PP Nomor 17 Tahun 2010 tentang Pengelolaan dan Penyelenggaraan Pendidikan sesuai pasal $58 \mathrm{H}$ ayat 1 dan ayat 2 ditegaskan bahwa pemerintah daerah sesuai dengan kewenangannya masing-masing menanggung seluruh biaya investasi, biaya operasioanal, beasiswa, dan bantuan biaya pendidikan dasar yang diselenggarakan oleh pemerintah dan pemerintah daerah sesuai dengan kemampuan.

Pendidikan Gratis diharapkan bisa mengurangi kesenjangan pendidikan antara masyarakat kaya dan miskin, serta kesenjangan antara wilayah kota dan desa meningkatkan angka siswa melanjutkan sekolah, dan menengkankan angka drop out (DO).

Dalam perkembangan pendidikan, masalah biaya menjadi masalah paling sentral untuk dipikirkan oleh para pengelola pendidikan, karena biaya dianggap akan menghambat proses pendidikan yang nantinya akan menyangkut pada masalah sarana prasarana, proses pembelajaran, dan tenaga pendidik. Keterbatasan biaya mengakibatkan banyak orang tua yang enggan menyekolahkan anaknya ke tingkat yang lebih tinggi sehingga tingkat siswa yang melanjutkan sekolah rasionya rendah.

Pendidikan Gratis bertujuan untuk meringankan beban masyarakat/orang tua/wali siswa dengan bentuk kegiatan pembebasan dari kewajiban membayar biaya operasional SD/MI, SMP/MTs yang selama ini ditanggung oleh masyarakat/orang tua/wali siswa.

Secara umum Pendidikan gratis bertujuan untuk meringankan beban masyarakat/orang tua/wali siswa terhadap pembiayaan pendidikan dalam rangka rintisan wajib belajar 12 tahun yang bermutu, serta berperan dalam mempercepat pencapaian Standar Pelayanan Minimal (SPM), dan mempercepat pencapaian Standar Nasional Pendidikan (SNP).

PPG sebagai upaya pemerintah dalam pemerataan pendidikan dalam arti pemerataan kesempatan untuk memperoleh pendidikan. Di pihak 
lain, maksud dan tujuan Program Pendidikan Gratis bagi masyarakat masih kurang jelas sehingga dalam menyampaikan pesan ini memerlukan bahasa pendekatan yang tepat. Kebijakan yang kerapkali merepotkan adalah ketika tujuan kebijakan pemerintah secara logika tidak mampu ditranformasi secara linier dengan cara berpikir dan kepentingan rakyat.

Logika masyarakat bahwa gratis itu adalah gratis segalanya, tidak ada pungutan sepeser pun. Inilah yang seharusnya mendapat perhatian pemerintah bahwa pengertian gratis berbeda dengan asumsi masyarakat. Istilah pendidikan gratis perlu dipertegas karena pendidikan gratis adalah kebutuhan dasar yang dijamin undang-undang.

Program Pendidikan Gratis memunculkan harapan bagi masyarakat yang memiliki tingkat ekonomi rendah untuk kelanjutan sekolah anak-anaknya dan prestasi siswa dapat meningkat dan terbebas dari putus sekolah serta buta aksara. Aplikasi dari kebijakan tersebut perlu dikawal dan dikaji dari berbagai aspek agar tepat sasaran dan tidak melenceng dari konsep sebenarnya.

Dalam penelitian ini sekolah yang dijadikan tempat penelitian yaitu Madrasah Ibtidaiyah (MI) Darul Ibad Kecamatan Ajung Kabupaten Jember. Alasan peneliti memilih MI Darul Ibad kerena merupakan lembaga pendidikan swasta yang berada di bawah naungan Yayasan Pendidikan Islam yang melaksanakan Pendidikan Gratis.

Sekolah swasta berbeda dengan negeri yang honor gurunya sebagian besar pemerintah yang bayar. Bagaimana dengan swasta? Kurang lebih $60 \%-80 \%$ sekolah yang menanggung. Belum kegiatan ekstra atau lainnya, hampir semua biaya dari sumbangan orang tua dipergunakan untuk operasional sekolah.

Dari segi sarana prasarana, jelas sekolah swasta membutuhkan dana untuk menunjang sarana prasarana, apalagi jika sekolah mendapatkan dana blok grant untuk pembangunan, maka mau tidak mau harus ada dana sharing untuk menunjang sarana prasarana. Jika sekolah masih 
menarik biaya kepada orang tua, maka tanggapan dari orang tua akan tidak baik pada sekolah sehingga bagi sekolah swasta akan dirugikan karena siswa yang daftar sedikit.

Tetapi karena masyarakat penduduk sekitar sekolah MI Darul Ibad adalah suku madura yang agamis dan MI Darul Ibad banyak pendidikan agamanya sehingga

\section{TINJAUAN PUSTAKA}

\subsection{Implementasi}

Implementasi adalah tindakantindakan yang dilakukan pihak-pihak yang berwenang atau kepentingan baik pemerintah maupun swasta yang bertujuan untuk mewujudkan cita- cita atau tujuan yang telah ditetapkan, implementasi dengan berbagai tindakan yang dilakukan untuk melaksanakan atau merealisasikan program yang telah disusun demi tercapainya tujuan dari program yang telah direncanakan karena pada dasarnya setiap rencana yang ditetapkan memiliki tujuan atau target yang hendak dicapai. warga masyarakat sekitar menyekolahkan anaknya ke ke lembaga MI Darul Ibad.

Berdasarkan uraian latar belakang diatas, maka masalah dalam penelitian ini adalah "Bagaimana Implementasi Program Pendidikan Gratis di MI Darul Ibad Ajung Jember?"

\subsection{Program}

Program merupakan tahap-tahap dalam penyelesaian rangkain kegiatan yang berisi langkah-langkah yang akan dikerjakan untuk mencapai tujuan dan merupakan unsur pertama yang harus ada demi tercapainya kegiatan implementasi. Program akan menunjang implementasi, karena dalam program telah dimuat berbagai aspek antara lain (Manila, 1996: 43):

a. Adanya tujuan yang akan dicapai.

b. Adanya kebijaksanaankebijaksanaan yang diambil dalam mencapai tujuan itu. 
c. Adanya aturan-aturan yang harus dipegang dan prosedur yang harus didahului.

d. Adanya perkiraan anggaran yang dibutuhkan.

e. Adanya strategi dalam pelaksanaan.

\subsection{Implementasi Pogram}

Implementasi Program adalah penerapan suatu kegiatan yang telah dirancang atau direncanakan, yang kemudian harus dijalankan dan dilaksanakan untuk pencapaian suatu tujuan, atau sebuah kegiatan pemahaman manusia mengenai pemecahan masalah. Donald P.Warwick dalam bukunya Syukur Abdullah (1998:7) mengatakan bahwa dalam tahap implementasi program terdapat dua faktor yang mempengaruhi keberhasilan yaitu faktor pendorong (facilitating conditions), dan faktor penghambat (impending conditions).

a. Faktor pendorong Yang termasuk kondisikondisi atau faktor pendorong adalah:

1) Komitmen pimpinan politik
2) Kemampuan organisasi

a) Kemampuan teknis

b) Kemampuan dalam menjalin hubungan dengan organisasi lain

3) Komitmen para pelaksana implementasi

4) Dukungan dari kelompok pelaksana

b. Faktor penghambat Yang termasuk kondisikondisi atau faktor penghambat terdiri dari:

1) Banyaknya pemain atau aktor yang terlibat

2) Terdapat komitmen atau loyalitas ganda.

3) Kerumitan yang melekat pada program itu sendiri.

4) Jenjang pengambilan keputusan

\subsection{Teori}

Implementasi

\section{Kebijakan Model Van Meter dan} Van Horn

Menurut Van Meter dan Van Horn yang dikutip Wahab (2008:78) menyatakan bahwa, "perbedaanperbedaan dalam proses implementasi akan dipengaruhi oleh 
sifat kebijaksanaan yang akan dilaksanakan". Model implementasi kebijakan yang dikembangkan oleh
Van Meter dan Van Horn (dalam Wahab, 2008:80) digambarkan sebagai berikut.

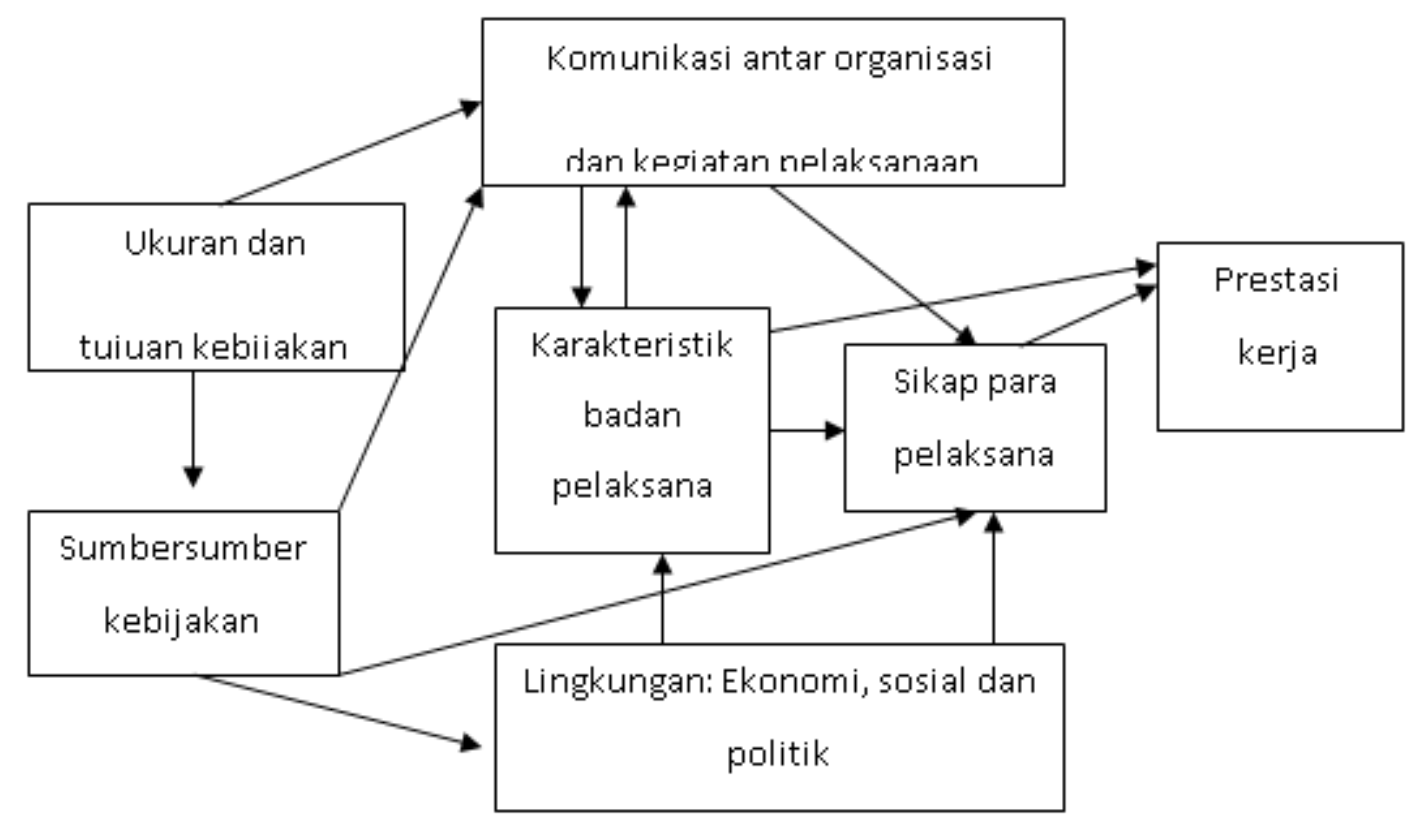

Gambar 1. Model Implementasi Kebijakan Van Meter dan Van Horn

Peneliti menggunakan model implementasi kebijakan yang dikemukakan Van Meter dan Van Horn. Implementasi Van Meter dan Van Horn (1975) merumuskan implementasi ini adalah sebagai tindakan-tindakan yang dilakukan baik oleh individu-individu, pejabatpejabat, atau kelompok-kelompok pemerintah atau swasta yang diarahkan pada tercapainya tujuantujuan yang telah digariskan dalam keputusan kebijakan (Wahab, 2005: 64). Dalam model yang dikembangkannya, Van Meter dan Van Horn mengemukakan ada faktor kritis yang mempengaruhi keberhasilan atau kegagalan implementasi. Variabel tersebut adalah:

1. Ukuran dan Tujuan Kebijakan

2. Sumber-sumber Kebijakan

3. Komunikasi antar Organisasi terkait dan Kegiatan-kegiatan Pelaksanaan 
4. Karakteristik Badan Pelaksana

5. Kondisi-kondisi Ekonomi, Sosial dan Politik

6. Kecenderungan Pelaksana (Implementors)

Yang keseluruhannya saling berhubungan dan saling mempengaruhi satu sama lain dalam menentukan keberhasilan atau kegagalan implementasi. Kajian yang dijelaskan oleh Van Meter dan Van Horn sangat sesuai dengan proses Implementasi Pendidikan Gratis yang mana proses ini dalam keberhasilannya ditentukan oleh berbagai faktor-faktor yang saling berhubungan. Peneliti pada nantinya akan menganalisis implementasi Pendidikan Gratis dengan pendekatan dari faktor Ukuran dan Tujuan Kebijakan, Sumber-sumber kebijakan, Komunikasi antar Organisasi dan Kegiatan-Kegiatan Pelaksanaan, Karakteristik BadanBadan Pelaksana, Kondisi-kondisi Ekonomi, Sosial, dan Politik. Kecenderungan Pelaksana (Implementator).

\subsection{Penyelenggaraan Pendidikan Gratis}

Implementasi Pendidikan Gratis adalah suatu kebijakan yang telah ditetapkan oleh Pemerintah Kabupaten Jember agar permasalahan biaya sekolah dapat teratasi, Hal ini dilakukan karena masyarakat menganggap terlalu besar biaya untuk menyekolahkan anaknya. Program Penyelenggaraan Pendidikan Gratis (PPG) adalah bantuan dana pendidikan dan salah satu program unggulan Pemerintah Daerah Kabupaten Jember. Program pendidikan gratis adalah salah satu layanan (service).

Pengelolaan program PPG mengacu pada konsep Manajemen Berbasis Sekolah (School Based Management), yang mengandung arti, yaitu:
a. Partisipatif
b. Transparan
c. Akuntabel
d. Demokratis
e. Efektif dan Efisien
f. Tertib Administrasi dan Pelaporan
g. Pengaduan 


\section{METODE PENELITIAN}

Dalam sebuah penelitian, metode merupakan suatu hal yang sangat penting, karena dengan metode yang baik dan benar akan memungkinkan tercapainya suatu tujuan penting yang merupakan tujuan dari penelitian tersebut.

Metode penelitian merupakan prosedur atau langkah-langkah sistematis dalam memecahkan suatu masalah sesuai dengan ketentuannya. Dengan menggunakan metode penelitian diharapkan peneliti dapat memperoleh data yang dibutuhkan sesuai dengan permasalahn yang ada.

Menurut Bogdan (dalam Idrus, 2009:57), penelitian yang mengkaji secara rinci atas suatu peristiwa tertentu merupakan penelitian studi kasus. Sehubungan dengan hal tersebut, maka penelitian ini merupakan penelitian studi kasus, dengan sifat penelitian deskriptif kualitatif.

Penelitian kualitatif merupakan penelitian yang bermaksud untuk memahami fenomena yang dialami subjek penelitian misalnya perilaku, motivasi, tindakan dan sebagainya secara holistik, dengan cara mendeskripsikan dalam bentuk kata dan bahasa, pada suatu konteks khusus dan dengan memanfaatkan berbagai metode ilmiah (Moleong, 2005: 6).

Sedangkan yang dimaksud dengan penelitian deskriptif adalah penelitian untuk meneliti status kelompok manusia, suatu objek, suatu kondisi, suatu sistem pemikiran ataupun suatu peristiwa pada masa sekarang. Tujuan dari penelitian deskriptif adalah untuk mendeskripsikan secara sistimatis, aktual dan akurat mengenai fakta, sifat, serta hubungan antara hubungan yang diselidiki (Nazir, 1999: 63).

Yang dimaksud dengan penelitian deskriptif kualitatif adalah prosedur penelitian berdasarkan data deskriptif, yaitu berupa lisan atau kata tertulis dari seseorang subyek yang telah diamati dan dimiliki karakteristik bahwa data yang diberikan merupakan data asli yang tidak diubah serta menggunakan cara yang sistematis dan dapat dipertanggungjawabkan kebenarannya. 


\section{HASIL PENELITIAN DAN PEMBAHASAN}

Pendidikan merupakan hal yang amat penting dalam komunitas besar suatu Negara, dimana pendidikan merupakan ujung tombak untuk menciptakan perkembangan dan kemajuan negara itu sendiri. Pendidikan gratis adalah segala pembebasan biaya bagi peserta didik dan orang tua peserta didik yang berkaitan dengan proses belajar mengajar dan kegiatan pembangunan dan pemeliharaan sekolah sesuai komponen yang mendapatkan anggaran dari Pemerintah Daerah.

Kemudian untuk memperoleh informasi dan data yang akurat tentang Implementasi Program Pendidikan Gratis maka peneliti melakukan wawancara mendalam serta studi dokumentasi. Adapun variabel-variabel atau faktor-faktor yang terdapat dalam model implementasi menurut Van Meter dan Van Horn terdiri dari:

1. Ukuran dan Tujuan Kebijakan.

2. Sumber-Sumber Kebijakan.

3. Komunikasi antar Organisasi terkait dan Kegiatan-kegiatan Pelaksanaan.
4. Karakteristik

Badan Pelaksana.

5. Kondisi-kondisi Ekonomi, Sosial dan Politik.

6. Kecenderungan Pelaksana (Implementors).

Enam faktor di atas yang akan digunakan sebagai alat analisis dalam kerangka seluruh proses yang ada dalam Implementasi Program Pendidikan Gratis di MI Darul Ibad Ajung Jember. Berdasarkan variabelvariabel atau faktor-faktor di atas dan data-data yang diperoleh di lapangan, kemudian dilakukan analisa sebagai berikut.

\subsection{Ukuran dan Tujuan} Kebijakan

Program Pendidikan Gratis bertujuan untuk meringankan beban masyarakat/orang tua/wali siswa dengan bentuk kegiatan pembebasan dari kewajiban membayar biaya operasional SD/MI, SMP/MTs yang selama ini ditanggung oleh masyarakat/orang tua/wali siswa.

Secara umum program pendidikan gratis bertujuan untuk meringankan beban 
masyarakat/orang tua/wali siswa terhadap pembiayaan pendidikan dalam rangka rintisan wajib belajar 12 tahun yang bermutu, serta berperan dalam mempercepat pencapaian Standar Pelayanan Minimal (SPM), dan mempercepat pencapaian Standar Nasional Pendidikan (SNP).

Secara khusus Program Penyelenggaraan Pendidikan Gratis bertujuan untuk:

1. Membebaskan pungutan bagi seluruh peserta didik SD/MI/SMP/MTs Negeri dan Swasta terhadap biaya operasional

Sekolah/Madrasah.

2. Membebaskan pungutan peserta didik dari seluruh pungutan dalam bentuk apapun, baik di Sekolah/Madrasah negeri maupun swasta, terkecuali bagi lembaga swasta yang menolak menerima dana PPG.

Berdasarkan hasil wawancara menunjukan bahwa semua pelaksana mengetahui ukuran dan tujuan kebijakan pendidikan gratis. Program penyelenggaraan pendidikan gratis membantu pelaksanaan proses pendidikan di madrasah. Tujuan dari pendidikan gratis dapat dirasakan oleh wali murid MI Darul Ibad terutama dalam hal pembiayaan SPP bagi siswa.

\subsection{Sumber-Sumber Kebijakan}

Sumber-sumber kebijakan yang di maksud adalah mencakup dana, personil, atau perangsang lain yang mendukung pelaksanaan kebijakan Implementasi Pendidikan Gratis di MI Darul Ibad Ajung Jember. Dana diperoleh dari APBD dan APBN.

Sumber dana untuk pembiayaan keberlangsungan Pendidikan Gratis diperoleh dari APBD Kabupaten Jember, per lembaga sekolah tidak sama pendapatan anggarannya dan alokasi anggaran madrasah tergantung pada kondisi siswa yang dimiliki sesuai dengan besaran dana yang tertulis di Juknis PPG yaitu Rp.20.000 persiswa. Jumlah anggaran yang diperoleh juga sudah sesuai dengan panduan Juknis PPG yaitu Alokasi PPG tiap SD/MI dihitung sebagai hasil rekapitulasi dari data jumlah peserta didik di tiap 
SD/MI yang ada di Dapodik dan EMIS pada tahun pelajaran yang sedang berjalan. Data jumlah siswa Sekolah MI Darul Ibad berdasarkan hasil observasi, jumlah siswa-siswi MI Darul Ibad Ajung Jember, secara keseluruhan ada 202 siswa.

Di petunjuk Juknis PPG Tahun 2017, penyaluran dana PPG dilaksanakan dalam 4 (empat) triwulan. Adapun tahapan penyaluran sebagai berikut:

a. Triwulan I : bulan Januari s.d Maret

b. Triuwaln II : bulan April s.d Juni

c. Triwulan III : bulan Juli s.d September

d. Triwulan IV : bulan Oktober s.d Desember

Penyaluran dana atau pencairan dana tidak tepat waktu dari Tim manajemen PPG yang membidangi pendidikan Gratis. Penyaluran dana atau pencairan dana tidak tepat waktu sangat berefek pada ketidak tepatan perencanaan program madrasah terutama program yang alokasi anggaran menggunakan anggaran pendidikan Gratis.
Dalam penyelenggaraan Pendidikan Gratis ada tiga tingkatan personel yang berperan, yakni:
a. Tim Manajemen Kabupaten
b. Tim Manajemen Kecamatan
c. Tim Manajemen pada Tingkat SD/MI, SMP/MTs

Personil yang membidangi pendidikan Gratis mumpuni dalam melakukan tugas penyelenggaraan pendidikan gratis.

\subsection{Komunikasi antar Organisasi terkait dan Kegiatan-kegiatan Pelaksanaan}

Komunikasi yang terjadi dalam Implementasi Pendidikan Gratis di MI Darul Ibad Ajung Jember adalah koordinasi pembagian tugas dan tanggung jawab. Selama 3 tahun terselenggarannya pendidikan gratis terjalin komunikasi yang baik antara pihak tim pengarahan manajemen, tim manajemen kabupaten, tim manajemen kecamatan, tim manajemen SD/MI. Dengan adanya sosialisasi dan pertemuan-pertemuan membahas tentang pendidikan gratis. Selanjutnya lembaga MI Darul Ibad mengadakan sosialisasi yaitu pertemuan wali murid bahwasannya 
akan menyelenggarakan pendidika gratis, yaitu tidak memungut biaya SPP.

Pendidikan Gratis sangat membantu pihak sekolah maupun masyarakat, namum masyarakat banyak beranggapan bahwa dana pendidikan gratis seluruhnya di tanggung pemerintah.

\subsection{Karakteristik}

Badan

\section{Pelaksana}

Karakteristik Badan dan instansi pelaksana berkaitan dengan kompetensi atau kinerja atau pembagian tugas pada pelaksana Pendidikan Gratis di MI Darul Ibad Ajung Jember. Seorang dikatakan kompeten atau mempunyai kinerja ketika dapat melakukan tugasnya dengan baik. Mengingat keberhasilan Pendidikan Gratis sangat ditentukan oleh keterpaduan kegiatan dari berbagai instansi. Karakteristik badan pelaksana Pendidikan Gratis berkompeten.

\subsection{Kondisi-kondisi Ekonomi, Sosial dan Politik}

Dampak kondisi kondisi ekonomi, sosial, dan politik pada kebijakan publik merupakan hal yang menjadi pusat perhatian. Keadaan atau kondisi lingkungan ekonomi, sosial dan politik sangat menentukan bagi pencapaian tujuan kebijakan yang dijalankan oleh badan badan pelaksana. Dalam hal ini pelaksanaan kebijakan atau program akan berjalan baik apabila keadaan atau kondisi ekonomi, social dan politik di daerah tersebut dalam penelitian ini adalah pemerintah kabupaten jember mendukung adanya kebijakan Pendidikan Gratis di MI Darul Ibad Ajung. Kondisi ekonomi peneliti fokuskan pada kesiapan dana dan fasilitas yang disediakan pemerintah untuk Implementasi Pendidikan Gratis di MI Darul Ibad Ajung, sedangkan kondisi sosial peneliti fokuskan pada sikap atau pandangan masyarakat MI Darul Ibad terhadap adanya program Pendidikan Gratis. Dan untuk kondisi politik, peneliti fokuskan pada bagaimana sikap pemerintah Kabupaten Jember terutama stakeholder terkait dalam implementasi pendidikan gratis.

Kondisi lingkungan ekonomi, sosial dan politik dari implementasi 
Pendidikan Gratis di MI Darul Ibad Ajung sangat mendukung. Hal ini terlihat dari adanya dana khusus yang disiapkan pemerintah, baik itu dari APBN dan APBD Kabupaten Jember. Dari kondisi sosial, wali murid MI Darul Ibad juga sangat mendukung adanya Pendidikan Gratis ini karena dengan adanya Pendidikan Gratis dapat meringankan beban orang tua. Pendidikan Gratis bertujuan untuk meringankan beban masyarakat/orang tua/wali siswa dengan bentuk kegiatan pembebasan dari kewajiban membayar biaya operasional SD/MI, SMP/MTs yang selama ini ditanggung oleh masyarakat/orang tua/wali siswa. Hal ini terjadi karena Secara umum Pendidikan gratis bertujuan untuk meringankan beban masyarakat/orang tua/wali siswa terhadap pembiayaan pendidikan dalam rangka rintisan wajib belajar 12 tahun yang bermutu, serta berperan dalam mempercepat pencapaian Standar Pelayanan Minimal (SPM), dan mempercepat pencapaian Standar Nasional Pendidikan (SNP).
Kondisi politik di Kabupaten Jember terkait dengan Pendidikan Gratis ini diimplementasikan terlihat sekali bahwa semua stakeholder yang terkait dalam hal ini mendukung adanya Pendidikan Gratis, mulai dari pihak Kepala Dinas Pendidikan Kabupaten, Kepala Kantor Kementrian Agama Kabupaten, Tim Manajemen Kecamatan, Tim Manajemen pada Tingkat SD/MI. Mereka mendukung kebijakan ini karena program ini dampaknya bagus bagi MI Darul Ibad. Hal ini terlihat dari adanya peningkatan jumlah peserta didik yang bersekolah di MI Darul Ibad.

\subsection{Kecenderungan Pelaksana (Implementors) \\ Kecenderungan pelaksana atau} sikap para pelaksana kebijakan (implementors) sangat penting diperhatikan, karena dengan pemahaman dan adanya dukungan terhadap Pendidikan Gratis maka pelaksanaan kebijakan tersebut akan berjalan sesuai dengan tujuan yang diharapkan dan sebaliknya. Dalam hal ini jika pelaksana sudah tidak setuju dengan adanya kebijakan 
tersebut, maka pelaksana tersebut melaksanakan kegiatan dengan setengah hati atau tidak maksimal.

Keberhasilan suatu program sangat dipengaruhi oleh Implementor Program itu sendiri. Hal ini tentu memiliki peran yang cukup besar dalam menentukan keberhasilan Program di MI Darul Ibad Ajung. Kepala sekolah, Guru, Komite

\section{KESIMPULAN DAN SARAN}

\subsection{Kesimpulan}

Berdasarkan hasil penelitian dengan menggunakan teori implementasi kebijakan Van Meter dan Van Horn,maka peneliti menyimpulkan hasil penelitian pendidikan gratis secara umum di MI Darul Ibad telah terlaksana dengan baik. Hal ini terbukti dengan pemenuhan yang menjadi indikator kebijakan pendidikan gratis terdiri dari Ukuran dan Tujuan Kebijakan, Sumber-sumber kebijakan,

Komunikasi antar Organisasi dan Kegiatan-Kegiatan Pelaksanaan, Karakteristik Badan-Badan Pelaksana, Kondisi-kondisi Ekonomi, Sosial, dan Politik. sekolah mensosialisasikan kepada masyarakat sekitar adanya Pendidikan Gratis sehingga masyarakat yang kurang mampu dapat menyekolahkan anaknya. Dengan adanya sosialisasi tersebut memberikan sumbangan yang signifikan bagi keberhasilan Pendidikan Gratis.

Kecenderungan

Pelaksana

(Implementator).

Berdasarkan data yang diperoleh dari wawancara, dokumentasi, dan studi pustaka dari keenam faktor di atas, maka dapat disimpulkan bahwa enam faktor tersebut saling mendukung terhadap pelaksanaan atau implementasi kebijakan yang nantinya arahnya pada prestasi kerja yang diharapkan yakni tercapainya tujuan-tujuan kebijakan seperti yang digambarkan oleh model implementasi Van Meter dan Van Horn Kebijakan ini adalah kebijakan yang sedang berjalan dan semua tujuan-tujuan Pendidikan Gratis di Madrasah 
Ibtidaiyah Darul ini terlaksana dengan baik.

Meskipun demikian masih ditemui dua indikator kebijakan pendidikan gratis belum terimplementasi dengan baik, yaitu: (1) penyaluran dana tidak dilakukan sesuai dengan petunjuk teknis PPG dan mengalami keterlambatan pencairan dana; dan (2) kurangnya pemahaman masyarakat atau orang tua yang banyak beranggapan bahwa dana pendidikan gratis seluruhnya di tanggung pemerintah.

\section{DAFTAR PUSTAKA}

Agustino, Leo. 2006. Dasar-dasar Kebijakan Publik. Bandung: Alfabeta.

Imron, Ali. 2008. Kebijaksanaan Pendidikan di Indonesia. Jakarta: Bumi Aksara.

Moleong, Lexy J. 2010. Metodologi Penelitian Kualitatif. Bandung: Remaja Rosdakarya.

Nazir, Moh. 1999. Metode Penelitian. Jakarta: Ghalia Indonesia.

Pemerintah Kabupaten Jember. 2017. Petunjuk Teknis Penyelenggaraan Pendidikan Gratis (PPG) SD/MI/SMP/MTs Negeri/Swasta. Jember: Pemerintah Kabupaten Jember.

\subsection{Saran}

Sebaiknya Pemerintah Kabupaten Jember tidak terlambat untuk mencairkan anggaran program penyelenggaraan pendidikan gratis agar cita-cita melahirkan generasi yang berkualitas karena ditempuh dalam dunia pendidikan tanpa memandang status, dan latar belakang perekonomian keluarga (antara siswa yang kaya dan miskin berhak mengenyam pendidikan) bisa dicapai dengan optimal.

Sugiyono. 2005. Metodologi Penelitian Kualitatif. Bandung: Alfabeta. 2012. Metode Penelitian Kualitatif dan $R \& D$. Bandung: Alfabeta. . 2014. Metode Penelitian Kombinasi. Cetakan VI: Bandung: Alfabeta.

Suharto, E. 2005. Analisis Kebijakan Publik. Edisi Revisi. Bandung: Alfabeta.

Thoha, Miftah. 2011. Birokrasi Pemerintah Indonesia di Era Reformasi. Jakarta: Kencana.

Wibawa, Samodra. 2004. Evaluasi Kebijakan Publik. Jakarta: Raja Grafindo Persada. 